\title{
Measuring serotonin synthesis: from conventional methods to PET tracers and their (pre)clinical implications
}

\author{
Anniek K. D. Visser • Aren van Waarde • Antoon T. M. Willemsen • Fokko J. Bosker • \\ Paul G. M. Luiten • Johan A. den Boer • Ido P. Kema • Rudi A. J. O. Dierckx
}

Received: 17 June 2010 / Accepted: 1 November 2010 /Published online: 27 November 2010

(C) The Author(s) 2010. This article is published with open access at Springerlink.com

\begin{abstract}
The serotonergic system of the brain is complex, with an extensive innervation pattern covering all brain regions and endowed with at least 15 different receptors (each with their particular distribution patterns), specific reuptake mechanisms and synthetic processes. Many aspects of the functioning of the serotonergic system are still unclear, partially because of the difficulty of measuring physiological processes in the living brain. In this review we give an overview of the conventional methods of
\end{abstract}

A. K. D. Visser $(\bowtie) \cdot$ A. van Waarde • A. T. M. Willemsen •

J. A. den Boer $\cdot$ R. A. J. O. Dierckx

Department of Nuclear Medicine and Molecular Imaging,

University of Groningen, University Medical Center Groningen,

Hanzeplein 1,

9700 RB, Groningen, The Netherlands

e-mail: visserakd@ngmb.umcg.nl

F. J. Bosker · J. A. den Boer

University Center of Psychiatry,

University of Groningen, University Medical Center Groningen,

Hanzeplein 1,

9700 RB, Groningen, The Netherlands

P. G. M. Luiten

Department of Molecular Neurobiology, University of Groningen,

Center for Behavior and Neurosciences,

Kerklaan 30,

9751 NN, Haren, The Netherlands

\section{P. Kema}

Department of Laboratory Medicine,

University of Groningen, University Medical Center Groningen, Hanzeplein 1,

9700 RB, Groningen, The Netherlands

R. A. J. O. Dierckx

Department of Nuclear Medicine, University Hospital Ghent,

De Pintelaan 185,

9000, Ghent, Belgium measuring serotonin synthesis and methods using positron emission tomography (PET) tracers, more specifically with respect to serotonergic function in affective disorders. Conventional methods are invasive and do not directly measure synthesis rates. Although they may give insight into turnover rates, a more direct measurement may be preferred. PET is a noninvasive technique which can trace metabolic processes, like serotonin synthesis. Tracers developed for this purpose are $\alpha-\left[{ }^{11} \mathrm{C}\right]$ methyltryptophan $\left(\left[{ }^{11} \mathrm{C}\right] \mathrm{AMT}\right)$ and 5-hydroxy-L- $\left[\beta-{ }^{11} \mathrm{C}\right]$ tryptophan $\left(\left[{ }^{11} \mathrm{C}\right] 5\right.$ HTP). Both tracers have advantages and disadvantages. $\left[{ }^{11} \mathrm{C}\right] \mathrm{AMT}$ can enter the kynurenine pathway under inflammatory conditions (and thus provide a false signal), but this tracer has been used in many studies leading to novel insights regarding antidepressant action. $\left[{ }^{11} \mathrm{C}\right] 5-\mathrm{HTP}$ is difficult to produce, but trapping of this compound may better represent serotonin synthesis. AMT and 5-HTP kinetics are differently affected by tryptophan depletion and changes of mood. This may indicate that both tracers are associated with different enzymatic processes. In conclusion, PET with radiolabelled substrates for the serotonergic pathway is the only direct way to detect changes of serotonin synthesis in the living brain.

Keywords Serotonin · Positron Emission Tomography . $\left[{ }^{11} \mathrm{C}\right] 5$-HTP $\cdot\left[{ }^{11} \mathrm{C}\right] \mathrm{AMT} \cdot$ Depression

\section{Introduction}

Serotonergic innervations are widely spread throughout the brain with cell bodies of origin lying in the dorsal (DRN) or median (MRN) raphe nucleus, and a column of raphe nuclei in lower brainstem regions, projecting to basically all divisions of the brain and spinal cord (Fig. 1). Synthesis 
of serotonin (5-HT) takes place within neurons and especially in serotonergic terminals, and this process includes two enzymatic steps. The first step is the conversion of the precursor molecule, the amino acid tryptophan (Trp), to 5-hydroxytryptophan (5-HTP) by tryptophan hydroxylase (TPH) 1 or 2 . The second step in the production of 5-HT involves the enzymatic action of aromatic amino acid decarboxylase (AADC) that has Ldopa and 5-HTP as a substrate. 5-HT is eventually degraded to 5-hydroxyindoleacetic acid (5-HIAA) by monoamine oxidase (MAO).

After synthesis, 5-HT is transported by the vesicular monoamine transporter and stored in vesicles at the neuronal presynaptic endings. When neurons fire, these vesicles fuse with the synaptic membrane and release 5-HT into the synaptic cleft. Released 5-HT can bind to many different receptors, both postsynaptic and presynaptic or be taken up by the serotonergic reuptake transporter (SERT). There are at least 15 different 5 -HT receptors which are divided into 7 distinct families $\left(5-\mathrm{HT}_{1-7}\right)$ [1]. Postsynaptic receptor binding can be either inhibitory or excitatory, depending on which subtype is stimulated. The presynaptic receptors $\left(5-\mathrm{HT}_{1 \mathrm{~A}}\right.$, located somatodendritic, and $5-\mathrm{HT}_{1 \mathrm{~B}}$, located on terminals) are autoreceptors that inhibit serotonergic neurotransmission, while heteroreceptors influence the release of neurotransmitters other than 5-HT [2]. Almost all 5-HT receptors are G protein-coupled (metabotropic), with the exception of the $5-\mathrm{HT}_{3}$ subtype which is a ligand-gated ion channel [1].

Different subtypes of the 5-HT receptor are located in different brain regions and probably regulate different behavioural functions. An important role of 5-HT is the regulation of mood, and several 5-HT receptor subtypes are involved in the actions of antidepressants and antipsychotics. Serotonin synthesis may be of special interest because this process is controlled by $5-\mathrm{HT}_{1 \mathrm{~A}}$ receptors, which are implied in the therapeutic efficacy of antidepressants [3].

It is clear that 5-HT influences many other neurotransmitter systems in an excitatory or inhibitory manner. One important key aspect that regulates serotonergic neurotransmission is the availability of the 5-HT precursor: the amino acid Trp.

In addition to conversion to serotonin, Trp is metabolized in the kynurenine pathway and used for protein synthesis. The rate-limiting step in the kynurenine pathway is the activity of indoleamine 2,3-dioxygenase (IDO) in the CNS and tryptophan 2,3-dioxygenase in peripheral organs. Both enzymes convert Trp to kynurenine. Activation of IDO within the CNS takes place under the influence of proinflammatory cytokines mainly within microglial cells. Increased cytokines and IDO activity have been linked to major depression in depressed subjects and in patients with inflammatory somatic disorders [4]. Increased IDO activity under inflammatory conditions may increase the amount of Trp used in the kynurenine pathway and consequently reduce the availability of Trp for 5-HT synthesis.

All the above-mentioned aspects of the serotonergic system may act in concert to enable the organism to function properly. The question is how can we obtain a reliable view of ongoing serotonergic processes in the living brain and what is the contribution of different receptor subtypes and determinants of 5-HT release (like its synthesis). Positron Emission Tomography (PET) can quantify these processes in a noninvasive manner. In Table 1, the most often used radiotracers to measure aspects of the serotonin system are listed [5-25]. Such tracers are reviewed elsewhere in greater detail [26, 27]. As there are no Single Photon Emission Computed Tomography
Fig. 1 The serotonergic system. The cell bodies of serotonergic neurons lay in the brainstem raphe nuclei. These neurons project to many brain areas like the cortex, basal ganglia, cerebellum, thalamus, limbic areas like hippocampus and amygdala, and spinal cord. Different 5HT receptor subtypes have a specific distribution in the brain. Autoreceptors in the raphe nuclei are depicted on neuronal cell bodies $\left(5-\mathrm{HT}_{1 \mathrm{~A}}\right)$ or in terminal areas and raphe nuclei on the presynapse $\left(5-\mathrm{HT}_{1 \mathrm{~B}}\right)$. The depiction of other 5-HT receptor subtypes in terminal areas can either represent heteroreceptors or postsynaptic receptors on 5HT neurons

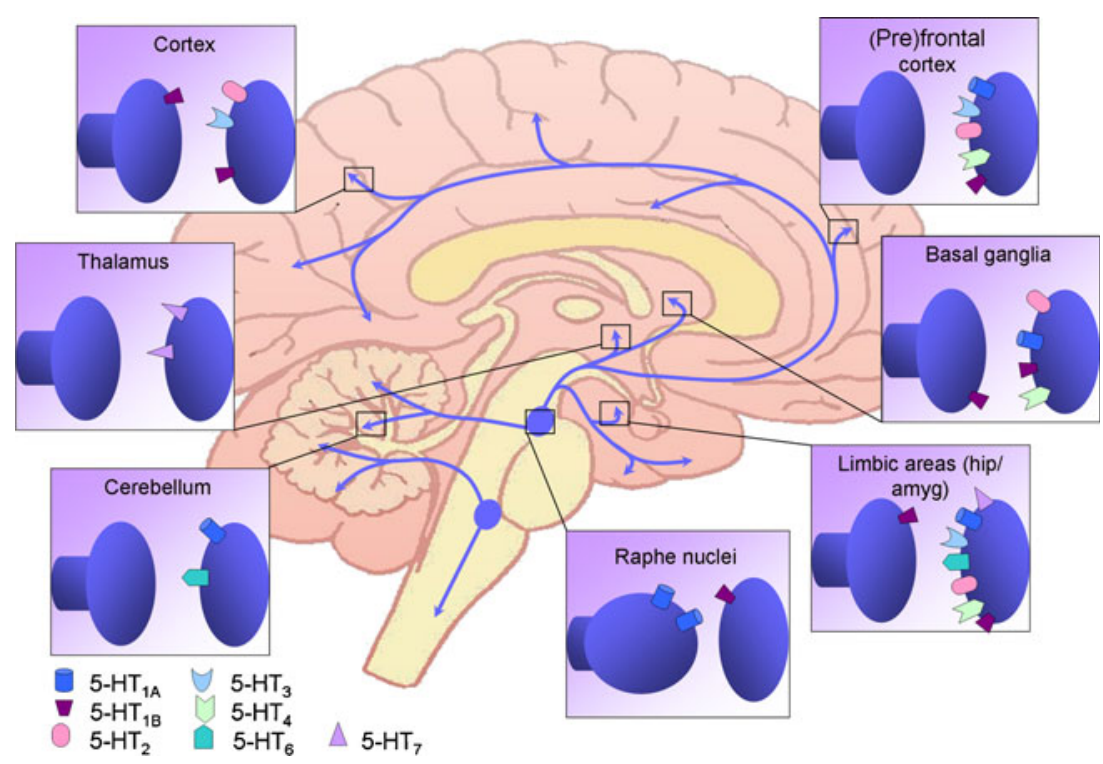


(SPECT) tracers to measure serotonin synthesis, we mention only PET tracers.

In the present review we will mainly focus on the quantification of serotonin synthesis and its preclinical and clinical application using conventional and PET imaging techniques.

\section{Conventional methods: measuring 5-HT and its metabolites in platelets and CSF}

In early studies of experimental animals, concentrations of 5HT and its metabolites in tissue after inhibition of AADC or MAO were used as an estimate of 5-HT turnover. Inhibiting MAO results in a decrease of the conversion of 5-HT to 5HIAA. By measuring either the reduction of 5-HIAA or the accumulation of 5-HT, turnover rates of 5-HT can be estimated. A similar approach is inhibition of the transport of 5-HIAA over the blood-brain barrier (BBB), from brain to the circulation. Inhibition of this transport by probenecid results in 5-HIAA accumulation within the brain, and the rate of this accumulation is related to the turnover rate of 5HT. The accumulation of 5-HTP in the brain after AADC inhibition with NSD-1015 can be used as a measure for 5HT synthesis. Assays of serotonin and its metabolites can be performed by analysis of tissue homogenates, by microdialysis or by analysis of body fluids (blood, urine or CSF) [28-30]. Such methods have four major disadvantages: (1) it is not certain that the target enzymes are fully inhibited under the conditions of the study, (2) the inhibitors may influence other physiological processes (for example 5-HT synthesis), (3) the measurements in plasma and urine include peripheral processes and (4) these invasive techniques cannot be applied in humans.

Table 1 PET tracers used for research on serotonergic neurotransmission

\begin{tabular}{|c|c|c|c|}
\hline $\begin{array}{l}\text { Serotonergic } \\
\text { component }\end{array}$ & Function & Radioligand & Literature \\
\hline \multirow[t]{9}{*}{$5-\mathrm{HT}_{1 \mathrm{~A}}$} & \multirow{9}{*}{$\begin{array}{l}\text { Autoreceptor on cell bodies in } \\
\text { DRN/inhibitory postsynaptic } \\
\text { receptor }\end{array}$} & {$\left[{ }^{11} \mathrm{C}\right] \mathrm{NAD}-195$} & Sandell et al. [22] \\
\hline & & {$\left[{ }^{18} \mathrm{~F}\right] \mathrm{MPPF}$} & Shiue et al. [23] \\
\hline & & {$\left[\right.$ carbonyl- $\left.{ }^{11} \mathrm{C}\right]$} & Pike et al. [19] \\
\hline & & WAY-100635 & \\
\hline & & $\begin{array}{l}{\left[\text { carbonyl- }{ }^{11} \mathrm{C}\right]} \\
\text { desmethyl-WAY- } \\
100635\end{array}$ & Pike et al. [20] \\
\hline & & {$\left[{ }^{18} \mathrm{~F}\right] \mathrm{FCWAY}$} & Lang et al. [13] \\
\hline & & {$\left[{ }^{18} \mathrm{~F}\right] \mathrm{MEFWAY}$} & $\begin{array}{l}\text { Saigal N., Synthesis and biologic evaluation of a novel serotonin 5- } \\
\text { HT1A receptor radioligand, } 18 \mathrm{~F} \text {-labeled mefway, in rodents and } \\
\text { imaging by PET in a nonhuman primate, } 2006\end{array}$ \\
\hline & & {$\left[{ }^{11} \mathrm{C}\right] \mathrm{RWAY}$} & Yasuno et al. [25] \\
\hline & & {$\left[{ }^{11} \mathrm{C}\right] \mathrm{CUMI}-101$} & Kumar et al. [12] \\
\hline \multirow[t]{2}{*}{$5-\mathrm{HT}_{1 \mathrm{~B}}$} & \multirow{2}{*}{$\begin{array}{l}\text { Autoreceptor on nerve terminals/ } \\
\text { inhibitory heteroreceptor }\end{array}$} & {$\left[{ }^{11} \mathrm{C}\right] \mathrm{AZ} 10419369$} & Pierson et al. [18] \\
\hline & & {$\left[{ }^{11} \mathrm{C}\right] \mathrm{P} 943$} & Gallezot et al. [8] \\
\hline \multirow[t]{4}{*}{$5-\mathrm{HT}_{2 \mathrm{~A}}$} & \multirow{4}{*}{$\begin{array}{l}\text { Excitatory receptor (e.g. } \\
\text { regulation gene transcription) }\end{array}$} & {$\left[{ }^{18} \mathrm{~F}\right]$ setoperone } & Blin et al. [6] \\
\hline & & {$\left[{ }^{18} \mathrm{~F}\right]$ altanserin } & Lemaire et al. [14] \\
\hline & & {$\left[{ }^{11} \mathrm{C}\right] \mathrm{MDL}-100907$} & Lundkvist et al. [15] \\
\hline & & {$\left[{ }^{18} \mathrm{~F}\right] \mathrm{MH} . \mathrm{MZ}$} & Herth et al. [10] \\
\hline $5-\mathrm{HT}_{4}$ & Excitatory receptor & {$\left[{ }^{11} \mathrm{C}\right] \mathrm{SB} 207145$} & Marner et al. [17] \\
\hline \multirow[t]{4}{*}{ SERT } & \multirow{4}{*}{$\begin{array}{l}\text { Reuptake transporter (e.g. target } \\
\text { SSRI) }\end{array}$} & {$\left[{ }^{11} \mathrm{C}\right] \mathrm{McN} 5652$} & Suehiro et al. [24] \\
\hline & & {$\left[{ }^{11} \mathrm{C}\right] \mathrm{DASB}$} & Houle et al. [11] \\
\hline & & {$\left[{ }^{11} \mathrm{C}\right] \mathrm{MADAM}$} & Halldin et al. [9] \\
\hline & & {$\left[{ }^{18} \mathrm{~F}\right] \mathrm{ADAM}$} & Ma et al. [16] \\
\hline Trp & $\begin{array}{l}\text { Precursor 5-HTP and substrate } \\
\text { TPH }\end{array}$ & $\alpha-\left[{ }^{11} \mathrm{C}\right]$ & methyltryptophan \\
\hline \multicolumn{4}{|l|}{$\begin{array}{l}\text { Diksic et al. } \\
\text { [7] }\end{array}$} \\
\hline 5-HTP & $\begin{array}{l}\text { Precursor 5-HT and substrate } \\
\text { AADC }\end{array}$ & $\begin{array}{l}\text { 5-hydroxy-L- } \\
{\left[\beta-{ }^{11} \mathrm{C}\right]} \\
\text { tryptophan }\end{array}$ & Bjurling et al. [5] \\
\hline
\end{tabular}


Turnover rates of 5-HT in humans are usually assessed by measuring 5-HT content of blood platelets or by analysis of samples of CSF which are acquired through lumbar puncture, an uncomfortable and invasive procedure. Usually the ratio of 5-HIAA and 5-HT is measured and sometimes only 5-HIAA concentrations are used as an index of 5-HT turnover (because 5-HT concentrations are negligible compared to 5-HIAA concentrations) [31]. Assays of platelet 5-HT content are of questionable value, since peripheral processes may not be an accurate reflection of the corresponding processes in the CNS. In research focusing on this question contradictory results were obtained.

Some studies indicate a close relationship between 5-HT turnover in brain and platelets. There are similarities between neurons and platelets regarding the mechanisms of 5-HT transport and the presence of certain binding sites including the $5-\mathrm{HT}_{2}$ receptor $[32,33]$. For example, rats show decreased levels of 5-HT both in platelet-rich plasma and in brain homogenates after the forced swim test (FST), used to assess antidepressant efficacy. This decrease is reduced after acute treatment of animals with a selective serotonin reuptake inhibitor (SSRI) (fluoxetine) and in naive rats, fluoxetine causes an increase in 5-HT [34]. The 5-HT concentration in brain homogenates after chronic (12 days) treatment of rats with an SSRI was comparable to the amount found in platelet-rich plasma. The 5-HT concentration in isolated platelets returned to control levels at day 12 , which may reflect comparable changes in neurons.

In contrast to these positive results, there is also evidence indicating that 5-HT in platelets and in brain may not always be changed in parallel. In $5-\mathrm{HT}_{1 \mathrm{~A}}$ receptor knockout mice, 5-HT concentrations in platelets and in brain show similar decreases until 2 weeks after birth. After 2 weeks, however, the 5-HT content of platelets is increased compared to wild-type mice, whereas brain 5-HT concentrations are normalized [34]. In addition, no correlation was observed between the binding potential of the $5-\mathrm{HT}_{2 \mathrm{~A}}$ ligand $\left[{ }^{18} \mathrm{~F}\right]$ setoperone in the brain and binding of $\left[{ }^{3} \mathrm{H}\right] \mathrm{LSD}$ in blood platelets of healthy volunteers [35]. This indicates that extrapolation of measurements in blood platelets to 5HT neurotransmission in the brain is difficult. Such extrapolations must be performed with caution and direct measurements of 5-HT in the brain should be preferred.

Another alternative for directly measuring brain concentrations is measurement of 5-HT and its metabolites in samples of CSF acquired by lumbar puncture. Because the levels of 5-HT in CSF are very low (less then $10 \mathrm{pg}$ / $\mathrm{ml}$ ), measurements of 5-HT concentration cannot be used for determination of 5-HT turnover rates [36]. Another option is measuring 5-HIAA concentrations in CSF, because 5-HIAA is present in much greater quantities. Increases of 5-HIAA after inhibition of MAO or of 5-
HIAA transport by probenecid should correlate to the formation rate of 5-HT. However, this method has also many drawbacks [31]:

- A lumbar puncture is invasive and often experienced as unpleasant.

- Measurements of 5-HIAA concentrations will partly represent the rate of transport of 5-HIAA into the CSF.

- Because of the high concentrations of 5-HIAA compared to 5-HT, changes in 5-HIAA are only detectable after a delay of several hours.

- 5-HT concentrations in lumbar CSF are not an accurate reflection of cerebral 5-HT synthesis, since they partially reflect synthesis of 5-HT within the spinal cord. There is a gradient from cisterna magna to spinal subarachnoid as more 5-HT is synthesized in the brain than in the spinal cord.

- 5-HIAA is transported from brain and CSF, back into the bloodstream.

The last process can be inhibited by administration of probenecid, which blocks the active transport of acidic metabolites out of the brain and CSF. Measurements of 5HIAA in CSF and the "probenecid test" were frequently used by Van Praag and Korf [37]. Concentrations of 5HIAA were measured in the CSF at baseline and after administration of probenecid. By using this method they were one of the pioneers linking serotonin deficiency to depressive symptoms and proposed the "predisposition hypothesis" which is partially maintained even today. The increase of 5-HIAA concentrations after probenecid was lower in depressive patients compared to the control group. This indicates involvement of 5-HT in depression. The predisposition hypothesis was further based on different findings. A higher frequency of depression was observed in patients with 5-HT deficiency and this deficiency in 5-HT persisted even after a depressive episode. Additionally, the use of 5-HTP as a prophylactic agent reduced the rates of relapse in depressed patients [38, 39].

A recent study reported that 5-HIAA in the blood of patients with major depression, using a jugular vein catheter, were actually increased, suggesting increased 5HT turnover. This increase in 5-HIAA was reduced by SSRI treatment and dependent on the $s$ and $l$ allele polymorphisms of SERT [40]. This result conflicts with assumptions that 5-HT synthesis is decreased in depressed patients and that antidepressants cause an increase in 5-HT signal transduction. A possibility is that SSRIs influence 5HT synthesis differently under acute and chronic circumstances, but they could also indirectly influence breakdown of 5-HT by MAO resulting in decreased turnover. SSRIs may increase extracellular 5-HT concentrations and con- 
comitantly reduce 5-HT storage and breakdown because of the decreased reuptake of 5-HT.

Later it appeared that 5-HT deficiency is related to other behavioural dysfunctions like aggression and impulsivity, while not solely deficiencies in 5-HT neurotransmission underlie depressive symptoms. This led to the denosologization hypothesis implying that serotonergic dysfunction may be related to dimensions of behaviour cutting across diagnostic boundaries, and thus not necessarily show correlations with diagnostic entities [41]. This approach was probably systematically applied for the first time in imaging studies by the Ghent group (head R.A. Dierckx) through transnosological research of impulsivity using SPECT activation studies and $5-\mathrm{HT}_{2 \mathrm{~A}}$ receptor imaging in suicidality, eating disorders and personality disorders (in men and dogs) [42-45].

Depression has a multi-symptom pathology and may probably be caused by flaws in several neurotransmitter systems and molecular signalling pathways. Yet, the serotonergic system may play an important role as it is a modulatory system, influencing the activity of many other neurotransmitter pathways throughout the brain.

\section{Recent technologies: radiopharmaceuticals for measuring serotonin synthesis}

Recent technologies allow research in living animals and humans. PET is such a noninvasive technique that enables quantification of physiological processes by measuring tracer kinetics. PET can reveal the dynamics of biological processes like 5-HT neurotransmission. In the pathway for 5-HT synthesis, the availability of Trp determines the rate of 5HT formation; because the $\mathrm{K}_{\mathrm{m}}$ values of TPH and AADC are greater than the physiological Trp concentrations, the enzymes are not saturated [46, 47]. This means that both Trp and 5-HTP analogues can be used for measuring 5-HT synthesis rates. The first attempts at imaging 5-HT synthesis were conducted by labelling natural Trp with tritium. Some disadvantages were noted, like the incorporation of Trp into proteins which reduces tracer availability $[48,49]$. Therefore, other tracers have been developed with more favourable characteristics, such as $\alpha-\left[{ }^{11} \mathrm{C}\right]$ methyltryptophan $\left(\left[{ }^{11} \mathrm{C}\right] \mathrm{AMT}\right.$, Trp analogue $)$ and 5-hydroxy-L- $\left[\beta-{ }^{11} \mathrm{C}\right]$ tryptophan $\left(\left[{ }^{11} \mathrm{C}\right] 5\right.$ HTP, radiolabelled 5-HTP).

$\alpha-\left[{ }^{11} \mathrm{C}\right]$ methyltryptophan

As Trp turned out to be unsuitable as a tracer, a radiolabelled analogue of Trp was introduced for measurement of 5-HT synthesis, $\alpha$-methyltryptophan (AMT). This compound is a substrate of TPH and will eventually be converted to $\alpha$ methylserotonin. Because $\alpha$-methylserotonin is not degraded by MAO and cannot cross the $\mathrm{BBB}$, it is trapped for a long period in the brain [50].

\section{Preclinical data}

Kinetic modelling and validation The first studies employed AMT labelled with ${ }^{3} \mathrm{H}$ and ${ }^{14} \mathrm{C}$ to perform autoradiography in rats. A kinetic model for measuring $\left[{ }^{14} \mathrm{C}\right] \mathrm{AMT}$ uptake was developed using a three-compartment model (or two-tissue compartment model) with irreversible tracer trapping, the compartments being plasma, brain and irreversibly trapped tracer [7, 51]. The slope of the linear function depicting distribution volume (DV) plotted against time under steadystate conditions represents the unidirectional trapping of the tracer indicated by the constant $\mathrm{K}^{\alpha}$. Subsequent studies used AMT labelled with ${ }^{11} \mathrm{C}$ for PET scanning in monkeys and dogs to measure individual rate constants and to enable Patlak analysis.

In this model, the $\mathrm{K}^{\alpha}$ (or $\mathrm{K}$ complex) describes a trapping constant that takes all individual rate constants into account according to the following formula:

$K^{\alpha}=\frac{K_{1}^{\alpha} k_{3}^{\alpha}}{\left(k_{2}^{\alpha}+k_{3}^{\alpha}\right)}$

In Eq. $1, \mathrm{~K}_{1}$ resembles tracer influx into the brain, $\mathrm{k}_{2}$ is the efflux constant and $\mathrm{k}_{3}$ the irreversible trapping constant (Fig. 2).

To estimate physiological rates of 5-HT synthesis, $\mathrm{K}^{\alpha}$ must be divided by a lumped constant (LC) to correct for difference in affinity of AMT and Trp for TPH and the different amounts of both compounds entering the kynurenine pathway. The $\mathrm{LC}$ is on average 0.42 in rat brain [52, 53]. In this way, a $\mathrm{K}^{\mathrm{T}}$ value can be obtained which is further converted to 5-HT synthesis rates by multiplication with free $\operatorname{Trp}$ concentrations in plasma $\left(\mathrm{Cp}^{\mathrm{Trp}}\right)$. Thus, reliable in vivo 5-HT synthesis rates $(\mathrm{R})$ may be estimated [54]:

$R=\left(\frac{K^{\alpha}}{L C}\right) *\left(C p^{T r y p}\right)$

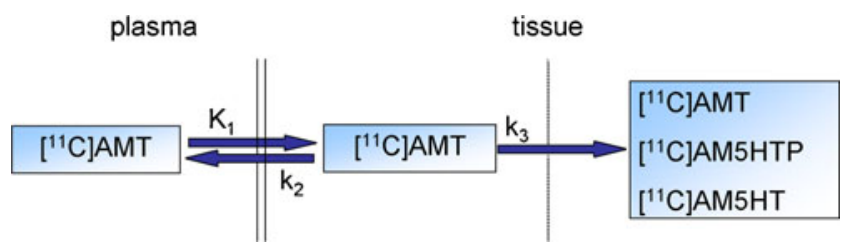

Fig. 2 Three-compartment model, or two-tissue compartment model, with irreversible tracer trapping. $\left[{ }^{11} \mathrm{C}\right] \mathrm{AMT}$ in plasma is transported over the $\mathrm{BBB}$ into the brain, where it can be irreversibly trapped, mainly as $\left[{ }^{11} \mathrm{C}\right]$ AMT but also as $\left[{ }^{11} \mathrm{C}\right]$ AM5HTP or $\left[{ }^{11} \mathrm{C}\right] \mathrm{AM} 5$ HT. The three compartments are plasma, precursor pool and irreversible trapping compartment 
$\mathrm{K}^{\alpha}$ can also be measured with a graphical method like the Patlak plot [55]. This graphical method is not constrained by individual rate constants, but based on macrosystem parameters, usually resulting in less variability. The slope of the Patlak plot represents $\mathrm{K}^{\alpha}$.

However, there are some contradictory results concerning the efficiency and reliability of radiolabelled AMT. In the first $60 \mathrm{~min}$ after injection, only a small fraction of labelled AMT is converted to labelled AM5HT in the rat brain [56]. Different research groups have obtained significantly different results in calculating the percentage of radioactivity corresponding to $\left[{ }^{11} \mathrm{C}\right] \mathrm{AM} 5 \mathrm{HT}$ in the DRN, ranging from $2-4 \%$ after 90 min in monkeys [57] to $31 \%$ after $60 \mathrm{~min}$ in rats [7]. It has been suggested that AMT PET measures Trp uptake in the brain rather than rates of 5-HT synthesis [57], although Diksic and colleagues argue that the significantly better fit of a three-compartment model compared to a two-compartment model suggests irreversible tracer trapping and not only the presence of AMT in the brain [58]. The slow kinetics resulted in the lack of a linear portion of the Patlak plot at the moment of tracer equilibrium between reversible compartments and plasma $[57,59]$. Gharib and colleagues correctly pointed out that AMT does not meet all the assumptions made in the Patlak model [56]. The transfer of unmetabolized tracer between brain and plasma is not fully reversible. Another problem is that labelled AMT can enter the kynurenine pathway since it is an analogue of Trp and the activity of this pathway will increase the amount of radioactivity which is trapped in the brain. Therefore, Chugani and Muzik refer to the measured $\mathrm{K}^{\alpha}$ as a reflection of the capacity of 5-HT synthesis, rather than the synthesis rate [59].

Although a kinetic analysis of AMT uptake may not provide true synthesis rates, labelled AMT is sensitive enough to detect physiological changes and may provide more information about serotonergic neurotransmission. Neurons stained for 5-HT or TPH were colocalized with $\left[{ }^{3} \mathrm{H}\right]$ AMT in the rat brain and $\left[{ }^{3} \mathrm{H}\right]$ AMT5HT was released from serotonergic cell bodies in the raphe nucleus and serotonergic terminals in projection areas like the hippocampus and striatum. This release was increased after depolarization by $50 \mathrm{mM} \mathrm{KCl}$, as compared to baseline [60]. Studies using autoradiography revealed that the half-life of the precursor pool in rats is approximately $20 \mathrm{~min}$ and treatment with lithium results in a $52 \%$ increase of $5-\mathrm{HT}$ synthesis rates in the parietal cortex and a $47 \%$ increase in the caudate nucleus $[7,51]$. This indicates the ability of AMT to detect changes in serotonergic neurotransmission.

Effect of pharmacological challenges Studies with ${ }^{14} \mathrm{C}$ labelled AMT in experimental animals using autoradiographic techniques after various interventions and brain lesions indicated that AMT could detect changes in the rate of 5-HT synthesis (see reviews by [31, 54]). These pharmacological interventions revealed differences in the acute or chronic effect of SSRIs on serotonin synthesis rates $[61,62]$ that could possibly be explained by autoreceptor stimulation.

This was also shown in a more recent study with the SSRI citalopram (10 mg/kg per day for 14 days) in olfactory bulbectomized (OBX) rats, a depression model. OBX rats showed an increase of 5-HT synthesis in terminal areas and reductions in the DRN. Chronic citalopram reduced 5-HT synthesis to the levels of sham-operated rats receiving citalopram in the terminal areas, and marginally increased synthesis in the DRN. As citalopram treatment in sham-operated rats also reduced 5-HT synthesis in some brain areas (DRN, hippocampus), the reduction of 5-HT synthesis in terminal areas of OBX rats may be explained by feedback inhibition through autoreceptors [63].

Autoreceptors located on serotonergic neurons are very important in the regulation of 5-HT synthesis and they play a crucial role in the therapeutic action of antidepressants. The 5-HT $1 \mathrm{~A}$ (somatodendritic receptor on cell bodies) and $5-\mathrm{HT}_{1 \mathrm{~B}}$ subtypes (presynaptic receptor on nerve terminals), regulating the feedback inhibition of 5-HT release, deserve attention because of their role in the late onset of therapeutic effects of many antidepressants.

Compared to the above-mentioned studies with antidepressants, similar effects were seen with the $5-\mathrm{HT}_{1 \mathrm{~A}}$ receptor agonist buspirone. Acute buspirone treatment of rats $(10 \mathrm{mg} / \mathrm{kg}$, subcutaneous) significantly decreased 5 -HT synthesis rates, while chronic treatment $(10 \mathrm{mg} / \mathrm{kg}$ per day for 14 days, subcutaneous) abolished this effect [64]. This finding is in accordance with previous results showing a reduction of serotonergic firing rate and reduced 5-HT in projection areas like the hippocampus [65, 66].

Less is known about the role of $5-\mathrm{HT}_{1 \mathrm{~B}}$ receptors on the nerve terminals in projection areas. The nonselective 5$\mathrm{HT}_{1 \mathrm{~B}}$ receptor agonists TFMPP and CGS12066B acutely decrease 5-HT synthesis rates in the DRN and MRN (probably caused by partial action on $5-\mathrm{HT}_{1 \mathrm{~A}}$ receptors) of rat brain [67]. Acute CGS12066B decreases 5-HT synthesis rates in brain areas known to contain solely 5$\mathrm{HT}_{1 \mathrm{~B}}$ receptors (e.g. the median of the nucleus caudatus and the nucleus accumbens) [68], while TFMPP decreases 5-HT synthesis in almost all terminal areas. Subchronic treatment (7 days) with both compounds decreases 5-HT synthesis in terminal areas.

The much more selective 5- $\mathrm{HT}_{1 \mathrm{~B}}$ receptor agonist $\mathrm{CP}$ 93129 when administered acutely $(7 \mathrm{mg} / \mathrm{kg}$, i.p.) decreased synthesis rates only in projection areas. This effect was abolished by chronic treatment $(7 \mathrm{mg} / \mathrm{kg}$ per day for 14 days, subcutaneous) which is explicable because of the desensitization of the 5- $\mathrm{HT}_{1 \mathrm{~B}}$ autoreceptors [69]. 
In conclusion, both $5-\mathrm{HT}_{1 \mathrm{~A}}$ and $5-\mathrm{HT}_{1 \mathrm{~B}}$ autoreceptors can reduce 5-HT synthesis rates in the brain, but the receptors desensitize in response to chronic stimulation, so that their inhibitory effects are transient.

These different effects of the pharmaceuticals are difficult to detect by simple measurements of 5-HT concentrations and made it clear that antidepressants have a regional specific effect on serotonin synthesis. Eventually effects on serotonin synthesis will influence the 5-HT availability for release and therefore may be a very important process in the efficacy of antidepressants. The studies with AMT described are excellent examples of how PET tracers can provide novel insights into physiological processes.

The most pronounced effects of pharmacological challenge are expected when the enzymes of the 5-HT synthesis pathway (AADC and TPH) are directly inhibited and this may provide information about the validity of the method. Indeed, the TPH inhibitor $p$-chlorophenylalanine (PCPA, $200 \mathrm{mg} / \mathrm{kg}$ for 3 days i.p.) and the inhibitor of TPH activation, AGN-2979 (10 mg/kg, i.p.), both reduced 5-HT synthesis rates [70, 71]. Surprisingly, the AADC inhibitor NSD-1015 (100 mg/kg, i.p.) appeared to increase 5-HT synthesis [72]. This discrepancy may be explained by the additional inhibition of MAO by NSD-1015 or by the ability of NSD-1015 to increase levels of free Trp in plasma [73]. Therefore, results obtained with NSD-1015 should be interpreted with caution as they are probably not solely attributable to inhibition of AADC.

Preclinical PET studies Although the above-mentioned studies may provide important insights regarding physiological processes in animals, autoradiography does not take individual rate constants into account. Higher accuracy can be obtained by monitoring tracer kinetics in living animals and humans using PET. The first study using ${ }^{11} \mathrm{C}$-labelled AMT for PET imaging was performed in dogs [74]. Both oxygen and Trp increased the trapping of $\left[{ }^{11} \mathrm{C}\right] \mathrm{AMT}$ in $\operatorname{dog}$ brain, which should be expected if $\left[{ }^{11} \mathrm{C}\right] \mathrm{AMT}$ trapping reflects 5-HT synthesis. Another experiment in dogs evaluated the time-dependent effect of 3,4-methylenedioxymethamphetamine (MDMA) infusion $(2 \mathrm{mg} / \mathrm{kg})$. After $1 \mathrm{~h}, 5$-HT synthesis was strongly increased (up to six times above baseline), though subsequently a decline in 5-HT synthesis rates was observed to $50 \%$ of baseline after $5 \mathrm{~h}$ [75]. This is in accordance with the observation that MDMA first stimulates 5-HT release which leads to increased 5-HT synthesis, but finally destroys 5-HT terminals with a corresponding decrease of neurotransmitter formation [76].

Interestingly, 5-HT synthesis rates measured with $\left[{ }^{11} \mathrm{C}\right]$ AMT PET in rhesus monkeys did not correlate with 5HIAA concentrations in the CSF. Whether this is due to a lack of accuracy of the AMT method or a difficulty of linking 5-HIAA in CSF to 5-HT synthesis within brain remains unclear [77], although in theory, during steady state there should be a close correlation between the conversion of 5-HT to 5-HIAA and the elimination of 5-HIAA from brain to CSF.

More concerns about the AMT method were raised by the same research group as they showed that even after $3 \mathrm{~h}$ in rhesus monkeys no equilibrium had been reached between tracer in plasma and tracer in reversible tissue compartments. Therefore, the Patlak plot showed no linear portion, which is necessary for calculation of influx rates [57].

However, the preclinical data contributed to the understanding of what the tracer is really measuring and whether the tracer is valid for clinical research, making it worthwhile to further investigate serotonin synthesis under clinical conditions.

\section{Clinical data}

Eventually a tracer should have the ability to visualize physiological processes in humans, in order to clarify the pathophysiology of disease and to be employed in routine clinical practice.

Human PET data of $\left[{ }^{11} \mathrm{C}\right] \mathrm{AMT}$ are modelled in approximately the same way as canine or monkey data (see above). However, in humans both a Patlak approach and a two-tissue compartment model can be used, although the value of the LC in humans is unknown. While in animals the Patlak approach may not be valid, in humans a steady state appears to be reached which is accompanied by a linear portion of the Patlak plot justifying its use for quantification purposes [78]. By comparing different studies in humans as well as in monkeys it was found that there was a high correlation between $\left[{ }^{11} \mathrm{C}\right] \mathrm{AMT}$ trapping, $\left[{ }^{11} \mathrm{C}\right] 5$-HTP accumulation and 5-HT concentrations determined postmortem [79].

A disadvantage of kinetic modelling is that an arterial cannula is required for blood sampling (determination of an arterial input function), which is a quite invasive procedure. The use of venous radioactivity as input causes a bias in the results with overestimation of the $\mathrm{K}^{\alpha}$ values, but this may be acceptable if no arterial blood samples can be taken [80].

The first study using $\left[{ }^{11} \mathrm{C}\right] \mathrm{AMT}$ PET focused on gender differences and Trp depletion [78]. Both females and males showed much lower $\mathrm{K}^{\alpha}$ values after acute Trp depletion through ingestion of a Trp-free amino acid mixture. The change was about $90 \%$ in males and $95 \%$ in females. Acute Trp depletion has been associated with lowered mood in vulnerable subgroups and with sensitivity to stress [81-83]. At baseline women had lower levels of free Trp in plasma 
than men. Possibly due to this difference in Trp levels, women showed lower rates of 5-HT synthesis than men at baseline, although the $\mathrm{K}^{\alpha}$ did not differ between genders. The $\mathrm{K}^{\alpha}$ should not be confused with rates of 5-HT synthesis which are also based on plasma levels of free Trp. Conflicting results were reported regarding gender differences. Where Chugani et al. [84] found an increase, Sakai et al. [21] described a decrease of the $\mathrm{K}^{\alpha}$ in females. These conflicting findings could be due to the different protocols that were employed including a different nutritional and metabolic state of the subjects.

Later studies focused on the effect of age on 5-HT synthesis and on the examination of various pathologies using $\left[{ }^{11} \mathrm{C}\right]$ AMT PET (see reviews by $[31,54]$ ).

More recent research has focused on the effect of oxygen on 5-HT synthesis, as it is necessary for TPH activity. Even slight hypoxia affects the metabolism of Trp, probably because TPH has a low affinity for oxygen [85]. This is reflected in the $\mathrm{K}^{\alpha}$ values measured under high and low oxygen concentrations (60 and $15 \%$ oxygen, respectively). The increase in the measured rate of 5-HT synthesis at high oxygen concentrations is about $50 \%$ [86], providing evidence that $\left[{ }^{11} \mathrm{C}\right] \mathrm{AMT}$ can be used for measuring changes of TPH activity.

When clinical applications for a tracer of 5-HT synthesis are considered, research on depressed patients is of great interest. Changes in Patlak $\mathrm{K}^{\alpha}$ were detectable with $\left[{ }^{11} \mathrm{C}\right] \mathrm{AMT}$ PET in medication-free patients with major depression [87]. Most obvious was the reduction of Patlak $\mathrm{K}^{\alpha}$ in the cingulate cortex (CC), bilaterally in women and in the left hemisphere in men. This brain area is involved in attention and emotion and shows abnormalities of cerebral blood flow and glucose metabolism in patients with major depression [88]. The CC receives large projections from the DRN and MRN and projects to orbitofrontal cortex (OFC) and amygdala, two areas hypothesized to show dysfunction in depression. Remarkably, no differences in 5-HT synthesis rate were found in the OFC or dorsolateral prefrontal cortex. This suggests that the difference in glucose metabolism observed in these regions may not be attributed to altered 5-HT synthesis. Surprisingly, $\mathrm{K}^{\alpha}$ did not correlate with the severity of depression [87].

Treatment with the SSRI citalopram increased $\mathrm{K}^{\alpha}$ in the $\mathrm{CC}$ and this increase is associated with elevated mood as assessed by Hamilton rating scores [89]. Other brain areas where citalopram increased 5-HT synthesis rates are the left and right prefrontal gyrus. These effects were not seen after 10 days, only after 24 days. This delay in the onset of therapeutic effects of an SSRI was probably caused by a feedback loop involving 5- $\mathrm{HT}_{1 \mathrm{~A}}$ autoreceptors. It is known that blocking the $5-\mathrm{HT}_{1 \mathrm{~A}}$ receptor with pindolol can accelerate the therapeutic effects of antidepressants [90].
Indeed, at day 24 the increase in 5-HT synthesis rate induced by an SSRI was greater in patients who received pindolol at day 10 compared to placebo. Whether this increase in 5-HT synthesis is due to $5-\mathrm{HT}_{1 \mathrm{~A}}$ autoreceptor blocking remains questionable, because pindolol also excites dopaminergic and noradrenergic neurons [91]. Most probably the total blockage of central beta-adrenoceptors by pindolol plays an important role [92].

In addition, the binding potential of $\left[{ }^{18} \mathrm{~F}\right] \mathrm{MPPF}$, a 5$\mathrm{HT}_{1 \mathrm{~A}}$ receptor ligand, could not be correlated to 5-HT synthesis rates as measured with $\left[{ }^{11} \mathrm{C}\right] \mathrm{AMT}$ in the raphe nuclei [93]. However, in terminal areas of serotonergic neurons (like hippocampus, anterior CC and anterior insula) a negative correlation was found, indicating that decreased binding of $\left[{ }^{18} \mathrm{~F}\right] \mathrm{MPPF}$ to $5-\mathrm{HT}_{1 \mathrm{~A}}$ heteroreceptors increased 5-HT synthesis. These studies show that a combination of different tracers can lead to greater understanding of processes in the human brain.

While under healthy conditions $\left[{ }^{11} \mathrm{C}\right] \mathrm{AMT}$ may give estimates of 5-HT synthesis, a recent human PET study confirmed that this tracer can actually enter the kynurenine pathway. It was shown that brain tumours show differences in IDO (the enzyme converting Trp to kynurenine) expression and that this expression was related to the amount of AMT taken up by the tumour [94].

\section{$\left[{ }^{11} \mathrm{C}\right] 5-\mathrm{HTP}$}

Tracer conversion to kynurenine can be prevented by labelling the direct precursor of 5-HT, which is only metabolized in the pathway for 5-HT synthesis. Injection of 5-HTP labelled in the $\beta$-position can provide insight into endogenously synthesized 5-HT, since 5-HTP is the substrate of the last enzyme involved in the production of 5-HT. $\left[{ }^{11} \mathrm{C}\right] 5$-HTP will undergo the same conversions as 5HTP and will eventually end up as $\left[{ }^{11} \mathrm{C}\right] 5$-HIAA (Fig. 3). Because of the difficulty of labelling 5-HTP in the $\beta$ position with ${ }^{11} \mathrm{C}$, a procedure which involves rapid enzymatic steps, this radiotracer has only been synthesized in a few imaging institutions $[5,95]$.

\section{Neuroendocrine tumour imaging}

$\left[{ }^{11} \mathrm{C}\right] 5$-HTP is mainly used for the detection of neuroendocrine tumours and not for brain imaging. These tumours are usually slowly growing, highly differentiated and may have various characteristics, although active uptake and decarboxylation of monoamine precursors like L-dopa and 5HTP and overproduction of hormones are typical. Conventionally used metabolic PET tracers, like $\left[{ }^{18} \mathrm{~F}\right] \mathrm{FDG}$, appeared unsuitable for the detection of neuroendocrine tumours, whereas detection of the uptake of monoamine precursors with $\left[{ }^{11} \mathrm{C}\right] 5$-HTP PET resulted in the visualiza- 


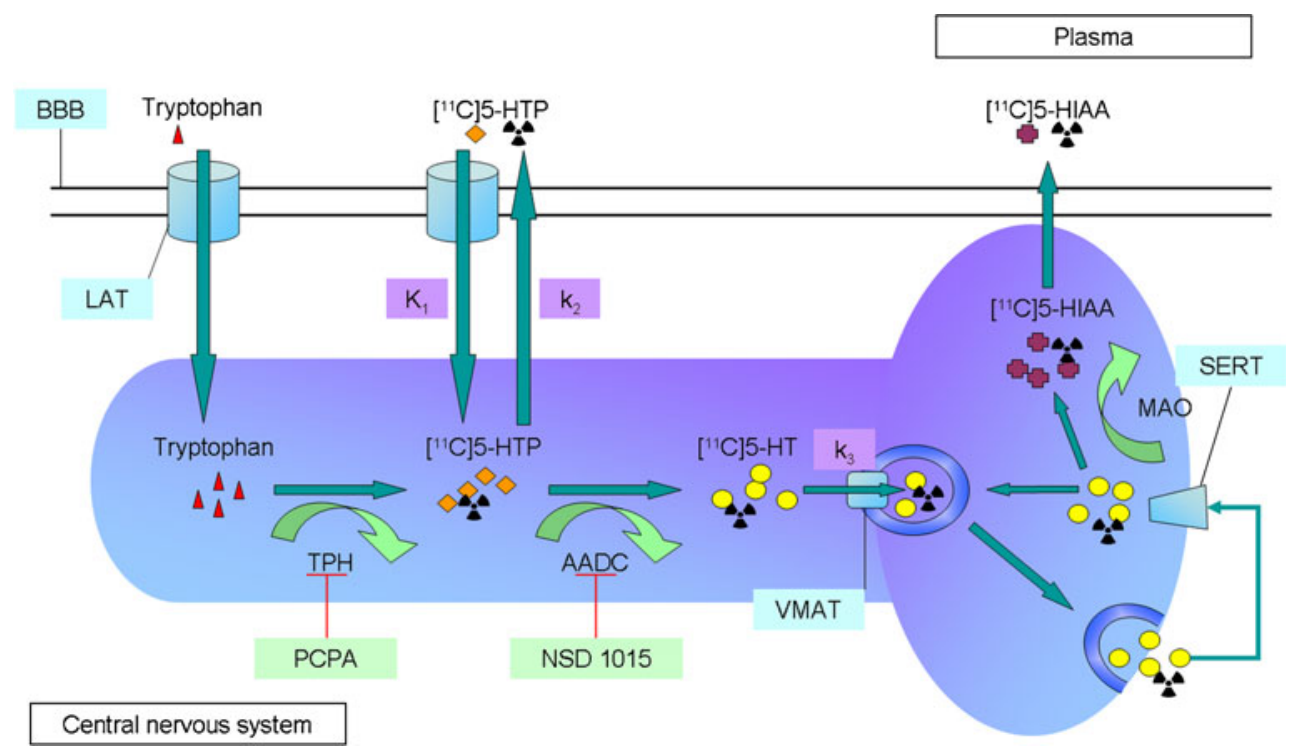

Fig. 3 Metabolism of $\left[{ }^{11} \mathrm{C}\right] 5-\mathrm{HTP}$. Most of 5-HT synthesis takes place in the terminal areas. Tryptophan is acquired through the diet and is transported across the blood-brain barrier $(B B B)$ by the large amino acid transporter $(L A T)$. Within neurons Trp is catabolized by tryptophan hydroxylase $(T P H)$ to 5-HTP. Subsequently, 5-HTP is converted to 5-HT by AADC. PCPA and NSD 1015 can block TPH and AADC, respectively. 5-HT is taken up and stored in vesicles by the vesicular monoamine transporter (VMAT). When neurons fire, the vesicles fuse with the synaptic membrane whereafter 5-HT is released within the synaptic cleft. The serotonin transporter (SERT) causes

tion of lesions which were missed by FDG. Especially the diagnostic sensitivity of pancreatic islet cell tumours greatly benefits from $\left[{ }^{11} \mathrm{C}\right] 5$-HTP PET in combination with a CT scan, while carcinoid tumours are better visualized with $\left[{ }^{18} \mathrm{~F}\right]$ FDOPA, a radiolabelled analogue of the precursor of dopamine [96].

However, a problem in this detection method is the high urinary concentration of ${ }^{11} \mathrm{C}$, caused by excretion of radiolabelled 5-HIAA. Inhibition of peripheral decarboxylase activity by administering the AADC inhibitor carbidopa reduces the excretion of ${ }^{11} \mathrm{C}$ and increases tracer uptake in the tumours [97, 98]. The effects of carbidopa on tracer uptake have also been investigated in a xenograft model of neuroendocrine pancreatic tumours by Neels and colleagues [99]. Carbidopa improved tumour imaging also in this animal model, probably by inhibiting peripheral AADC activity and increasing availability of the tracer.

\section{Preclinical data}

In 1992, an initial preclinical study with $\left[{ }^{11} \mathrm{C}\right] 5$-HTP for measuring cerebral 5-HT synthesis was performed in rhesus monkeys [100]. The authors used a reference area in the brain for modelling the time-activity curves of other brain areas, in order to analyse tracer kinetics. In this model the reuptake of 5-HT that can either be restored into vesicles or be broken down by monoamine oxidase ( $M A O)$ to 5-HIAA. Eventually, 5-HIAA is released into the bloodstream and excreted by the kidneys. A similar process takes place in peripheral organs. Radiolabelled 5-HTP undergoes the same conversions as endogenous 5-HTP and is therefore a suitable tracer for 5-HT synthesis. A two-tissue compartment model with irreversible tracer trapping can be used for modelling $\left[{ }^{11} \mathrm{C}\right] 5-\mathrm{HTP}$ kinetics. The rate constant for transport from plasma to brain is indicated by $K_{1}, k_{2}$ represents efflux of the tracer back into the bloodstream and $k_{3}$ is the irreversible trapping constant rate constant $\mathrm{k}_{3}$ represents irreversible tracer trapping (Figs. 2 and 3).

Since blocking of specific enzymatic steps in the metabolic pathway had the expected effects, $\left[{ }^{11} \mathrm{C}\right] 5$-HTP appeared to be a valid tracer for measurement of the rate of decarboxylation of 5-HTP to 5-HT. Blocking central AADC with NSD-1015 resulted in a decrease of the rate constant $\mathrm{k}_{3}$ in both monkeys and rats. This constant reflects 5-HTP decarboxylation and mirrors 5-HT synthesis. The nonspecific blocking of MAO with pargyline ( 2 days $2 \times 4 \mathrm{mg} / \mathrm{kg}$ ) or the selective blocking of MAO-A with clorgyline $(0.2 \mathrm{mg} / \mathrm{kg})$ did not change the rate constant indicating that radiolabelled 5-HIAA does not readily leave the brain $[100,101]$. Especially in the striatum, levels of radioactivity were high and the value of $k_{3}$ was influenced by the concentration of pyridoxine or vitamin $\mathrm{B}_{6}$, the cofactor of AADC [102].

Not only 5-HTP is a substrate of AADC, but also Ldopa, the precursor of dopamine. The affinity of AADC for 5-HTP is probably higher than for L-dopa [103]. When unlabelled substrates were administered to increase the size of the endogenous pools, the measured value of $k_{3}$ was decreased. This indicates a limited capacity of the enzyme for substrate conversion and saturation of the decarboxylation reaction [103]. The detriment of $\left[{ }^{11} \mathrm{C}\right] 5$-HTP is that AADC is not only present in serotonergic but also in 
dopaminergic and noradrenergic neurons, possibly trapping the tracer in these neurons as well [103, 104].

The only experiments with $\left[{ }^{11} \mathrm{C}\right] 5$-HTP in rodents were performed by Lindner and colleagues [101]. PET imaging was not performed in this study, but animals were sacrificed $40 \mathrm{~min}$ after tracer injection and highperformance liquid chromatography (HPLC) was used to separate $\left[{ }^{11} \mathrm{C}\right] 5$-HTP from its metabolites in brain extracts. At 40 min after injection, $95 \%$ of the radioactivity within the brain originated from $\left[{ }^{11} \mathrm{C}\right] 5-\mathrm{HTP},\left[{ }^{11} \mathrm{C}\right] 5-\mathrm{HT}$ and $\left[{ }^{11} \mathrm{C}\right] 5$-HIAA, the latter compound comprising $75 \%$ of total brain radioactivity. These data indicated an extensive metabolism of $\left[{ }^{11} \mathrm{C}\right] 5$-HTP in the 5 -HT synthesis pathway. Less than $5 \%$ of the cerebral radioactivity was related to other metabolites. By blocking the enzyme MAO, the fraction of 5-HT in the striatum was increased, which could be expected if MAO degrades 5-HT. Blocking of central AADC by NSD-1015 decreased the conversion of 5-HTP to 5-HT and 5-HIAA, while the blocking of peripheral AADC with carbidopa increased the brain uptake of 5-HTP, although it decreased the formation of 5-HIAA. Surprisingly, carbidopa increased $\mathrm{k}_{3}$ in the striatum indicating increased turnover of the tracer, but it lowered $\mathrm{k}_{3}$ in the cerebellum. The underlying mechanism is unclear.

Most of the above-mentioned research was performed with a reference tissue analysis or with HPLC rather than PET. HPLC can be used in preclinical research, but PET offers opportunities to visualize the living brain in humans. The most accurate way of determining tracer uptake in tissue is to relate this to plasma input, instead of using a reference tissue. An input function derived from arterial blood samples can be used to model time-activity curves in brain to characterize the cerebral kinetics of the tracer. The most suitable model for analysis of the kinetics of $\left[{ }^{11} \mathrm{C}\right] 5$ HTP is a two-tissue compartment model with irreversible tracer trapping (Fig. 3). This model is approximately the same as for $\left[{ }^{11} \mathrm{C}\right] \mathrm{AMT}$. The individual rate constants for tracer uptake $\left(\mathrm{K}_{1}\right)$, tracer efflux $\left(\mathrm{k}_{2}\right)$ and irreversible tracer trapping $\left(\mathrm{k}_{3}\right)$ can be used for calculating the accumulation constant $K_{\text {acc }}$ (see Eq. 1).

This model appears to be valid in the rhesus monkey, as it could detect changes in AADC activity after pharmacological manipulation, and elimination of $\left[{ }^{11} \mathrm{C}\right] 5$-HIAA was negligible within a scan time of $60 \mathrm{~min}$ [105].

In another study [106], the authors compared the ability of the PET tracers $\left[{ }^{11} \mathrm{C}\right] 5$-HTP and $\left[{ }^{11} \mathrm{C}\right]$ AMT to measure AADC activity in the monkey brain. It appeared that these tracers had different rate constants and accumulation rates. While $\left[{ }^{11} \mathrm{C}\right] \mathrm{AMT}$ showed higher uptake of radioactivity in the brain, which is not surprising because less $\left[{ }^{11} \mathrm{C}\right] 5$-HTP than $\left[{ }^{11} \mathrm{C}\right]$ AMT is available in plasma, the values of $\mathrm{K}_{1}, \mathrm{k}_{3}$ and $\mathrm{K}_{\mathrm{acc}}$ in striatum and thalamus were lower. The reason for a lower availability of $\left[{ }^{11} \mathrm{C}\right] 5$ HTP could be extensive decarboxylation of this tracer by AADC in peripheral organs. Remarkable is the fact that although 5-HT concentrations differ highly between different brain areas, the trapping of $\left[{ }^{11} \mathrm{C}\right] \mathrm{AMT}$ is rather uniform throughout the brain, while this is not the case for $\left[{ }^{11} \mathrm{C}\right] 5$-HTP [106].

\section{Clinical data}

To the best of our knowledge, the first PET study with $\left[{ }^{11} \mathrm{C}\right]$ 5-HTP in the human brain was performed in 1991 [107]. Patients suffering from major depression showed a reduced uptake of the tracer in their brains. A recent clinical study reported a relationship between $\left[{ }^{11} \mathrm{C}\right] 5$-HTP trapping and mood states [108]. A clear negative correlation was observed between the cardinal symptoms of premenstrual dysphoria in women, like irritability and depressed mood, and changes in tracer trapping in the entire brain (Fig. 4), prefrontal regions and some regions of the striatum. The opposite mood states, feelings of happiness and mental energy, showed a strong positive correlation with tracer trapping. The same two-tissue compartment model as was used for monkeys has been employed for PET studies of 5HT synthesis in the human brain [109]. Tracer influx should never be rate limiting or it will lower the $\mathrm{k}_{3}$. Hagberg and colleagues found a distribution volume above zero, indicating considerable tracer uptake in the brain. The constant that takes the distribution volume into account is the net accumulation rate constant $\mathrm{K}_{\mathrm{acc}}$, which is referred to as $\mathrm{K}^{\alpha}$ in $\left[{ }^{11} \mathrm{C}\right] \mathrm{AMT}$ PET.

There are only a few published reports on the use of $\left[{ }^{11} \mathrm{C}\right] 5$-HTP for imaging 5-HT synthesis, and thus there are many opportunities for clinical studies with this tracer. The correlation of tracer trapping with mood indicates that this method may be useful for assessing the therapeutic efficacy of antidepressants. Other pathological conditions may be elucidated using $\left[{ }^{11} \mathrm{C}\right] 5$-HTP PET, such as the role of serotonergic dysfunction in eating disorders.

\section{Discussion}

The serotonergic system is complex, influencing many other neurotransmitter systems and behavioural functions. Monitoring 5-HT synthesis or other elements of serotonergic neurotransmission in vivo with PET gives insight into what is going on in the living brain. Research reviewed here shows the possibilities of this technique to elucidate processes otherwise not fully understood. However, refinement is necessary to increase resolution and increase target to background ratios. In addition, many elements of the 5HT system have not yet been visualized, making the picture 
Fig. 4 Mood correlates with $\left[{ }^{11} \mathrm{C}\right] 5$-HTP trapping. Both positive and negative mood states are related to the amount of tracer trapping in the brain of women with premenstrual dysphoria. Especially irritability, depression, energy and happiness show strong correlations with $\mathrm{r}_{\mathrm{s}}$. VAS visual analogue scale, $r_{s}$ rate for $\left[{ }^{11} \mathrm{C}\right] 5$-HTP irreversible trapping. Reprinted from [108], with permission from Elsevier

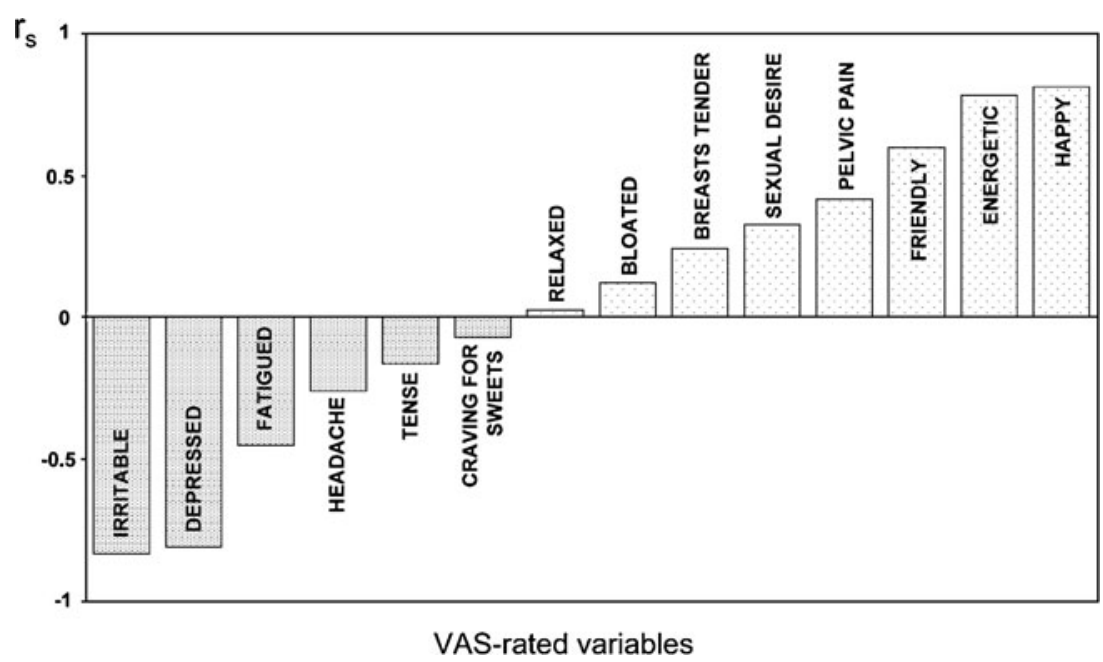

incomplete. The most elegant studies are studies where multiple tracers could be used, visualizing different aspects of serotonergic neurotransmission like receptor binding potential and 5-HT synthesis.

A dynamic process such as 5-HT synthesis cannot reliably be assessed by single time point measurements of 5-HT and its metabolites in CSF or blood platelets. Since 5HT synthesis is one of the initial processes in serotonergic neurotransmission and a crucial determinant of 5-HTmediated signal transduction, quantification of this process by PET is of great interest. Two tracers, $\left[{ }^{11} \mathrm{C}\right] 5$-HTP and $\left[{ }^{11} \mathrm{C}\right] \mathrm{AMT}$, have been developed for this purpose, which have distinct advantages and disadvantages.

A specific tracer that measures 5-HT synthesis rates may answer some of the questions about changes of 5-HT synthesis in different physiological or pathological conditions. Most important results show the effects of antidepressants on 5-HT synthesis through activation of autoreceptors, which may indicate a crucial role for 5-HT synthesis in the efficacy of antidepressants. This should be elucidated in future research.

As outlined above, more research has been done with $\left[{ }^{11} \mathrm{C}\right] \mathrm{AMT}$ than with $\left[{ }^{11} \mathrm{C}\right] 5-\mathrm{HTP}$, probably because producing $\left[{ }^{11} \mathrm{C}\right] 5$-HTP is difficult, requiring several enzymatic steps [110]. At the moment it is only produced in four to five centres all over the world.

The most striking difference between the results of AMT and HTP studies concerns the effect of Trp depletion and its correlation with mood states. While $\left[{ }^{11} \mathrm{C}\right] \mathrm{AMT}$ detects a large decrease in 5-HT synthesis rates after acute Trp depletion, $\left[{ }^{11} \mathrm{C}\right] 5$-HTP does not $[78,111]$. The opposite accounts for mood states; no correlation was found between $\left[{ }^{11} \mathrm{C}\right] \mathrm{AMT}$ radioactivity in the brain and Hamilton scores, whereas the brain uptake of $\left[{ }^{11} \mathrm{C}\right] 5-\mathrm{HTP}$ is correlated with different mood states $[87,108]$. The different results obtained with $\left[{ }^{11} \mathrm{C}\right] 5$-HTP and $\left[{ }^{11} \mathrm{C}\right] \mathrm{AMT}$ may be due to the fact that 5-HTP and AMT are substrates for different enzymes, AADC and TPH, respectively. The tracers may measure different aspects of Trp metabolism and 5-HT synthesis. There are some reasons why $\left[{ }^{11} \mathrm{C}\right] 5$-HTP may be preferred over $\left[{ }^{11} \mathrm{C}\right] \mathrm{AMT}$ :

- $\left[{ }^{11} \mathrm{C}\right] \mathrm{AMT}$ kinetics is very slow, resulting in a low production of $\left[{ }^{11} \mathrm{C}\right] \mathrm{AM} 5 \mathrm{HT}$ and a high fraction of trapped tracer representing [ $\left.{ }^{11} \mathrm{C}\right] \mathrm{AMT}$ (parent) [56].

- AMT is an analogue of Trp which behaves differently than the natural amino acid (Fig. 5).

- In rats and monkeys, equilibrium between irreversible compartments and plasma is not reached within a PET time scale. As a consequence of this, Patlak modelling produces erroneous results $[56,57]$.

- In contrast to $\left[{ }^{11} \mathrm{C}\right] 5-\mathrm{HTP},\left[{ }^{11} \mathrm{C}\right] \mathrm{AMT}$ can enter the kynurenine pathway since it is an analogue of Trp. This route becomes important under inflammatory conditions and it may cause difficulties in the interpretation of $\left[{ }^{11} \mathrm{C}\right] \mathrm{AMT}$ scan data [94].<smiles>N[C@@H](Cc1c[nH]c2ccc(O)cc12)C(=O)O</smiles>

["C]5-HTP

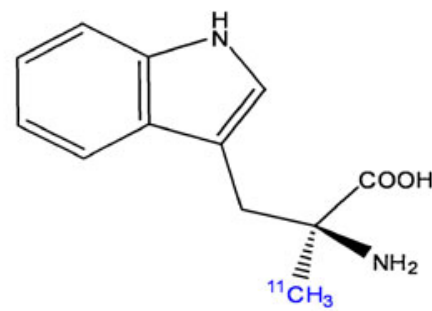

["C]AMT
Fig. 5 Chemical structures of $\left[{ }^{11} \mathrm{C}\right] 5-\mathrm{HTP}$ and $\left[{ }^{11} \mathrm{C}\right] \mathrm{AMT}$. The radionuclide ${ }^{11} \mathrm{C}$ (indicated in blue) is incorporated in the $\beta$-position of the carbon skeleton of 5-HTP, but in the methyl group of AMT 
Results obtained with $\left[{ }^{11} \mathrm{C}\right] \mathrm{AMT}$ under pathological conditions may reflect activation of the kynurenine pathway rather than 5-HT synthesis. Because 5-HTP is the endogenous direct precursor of 5 -HT its metabolic fate is much less complex (Fig. 5), even though AADC is also present in dopaminergic neurons to convert L-dopa into dopamine. After oral administration of 5-HTP in rats, the immunoreactivity of 5-HT and 5-HTP colocalized in the raphe nuclei, but also in the dopaminergic neurons in the substantia nigra pars compacta. This suggests that $\left[{ }^{11} \mathrm{C}\right]$ 5-HTP could also be converted to ectopic $\left[{ }^{11} \mathrm{C}\right] 5$-HT in dopaminergic neurons [112].

Thus, based upon these considerations we would prefer $\left[{ }^{11} \mathrm{C}\right] 5$-HTP PET for the study of alterations of 5-HT synthesis in different pathological conditions.

However, some prerequisites of the model used for calculating 5-HT synthesis rates with $\left[{ }^{11} \mathrm{C}\right] 5$-HTP should be mentioned. Erroneous data can be obtained if the biological system does not meet the following conditions:

- AADC must operate far from saturation, so that changes in the rate of 5-HT formation can be measured. This condition is probably met, because the tissue concentration of 5-HTP is below the Michaelis-Menten constant of AADC. However, the enzyme may approach saturation under conditions where 5-HT synthesis is strongly increased [103].

- 5-HIAA should not leave the brain within the time span of the scan. This metabolite is finally excreted, but MAO inhibition does not affect $\mathrm{k}_{3}$ indicating that within a 60 -min scan the loss of radiolabelled 5-HIAA from brain tissue is negligible [100].

- 5-HIAA from the blood should not contribute to measured radioactivity in the brain. 5-HTP is converted to 5-HT and 5-HIAA in peripheral organs. Although 5HT cannot be transported across the BBB, 5-HIAA can. However, plasma concentrations of 5-HIAA are only large at the end of the scanning period and MAO inhibition does not change the $\mathrm{k}_{3}$. Therefore, the contribution of 5-HIAA in the circulation to cerebral radioactivity is probably minor.

- Enough tracer should enter the brain as the amount of tracer should not be rate limiting. Therefore, the cerebral distribution volume must be above zero, as indicated by Hagberg and colleagues [109]. The delivery of $\left[{ }^{11} \mathrm{C}\right] 5$-HTP to the brain could be facilitated by intraperitoneal administration of carbidopa [99].

- Synaptic transport of Trp and 5-HTP should be limited to 5-HT neurons and AADC should be specific for 5HTP. Although L-dopa is also a substrate of AADC, it seems to influence $\left[{ }^{11} \mathrm{C}\right] 5$-HTP trapping to a lesser extent than cold 5-HTP, indicating that 5-HTP may be predominantly used by serotonergic neurons [103].
Most of these prerequisites have been investigated in humans and monkeys and the conditions for modelling $\left[{ }^{11} \mathrm{C}\right] 5$-HTP kinetics seem to be met in these species, but tracer validation for microPET studies in rodents has not yet been performed. $\left[{ }^{11} \mathrm{C}\right] 5$-HTP scans in rodents could be used in preclinical testing of the effects of antidepressants and provide new insight into the pathophysiology of disease. Future research should indicate whether $\left[{ }^{11} \mathrm{C}\right]$ 5-HTP and $\left[{ }^{11} \mathrm{C}\right] \mathrm{AMT}$ measure enzymatic activity (TPH, AADC, IDO) or the true rates of 5-HT synthesis.

The above-named prerequisites of measuring 5-HT synthesis with $\left[{ }^{11} \mathrm{C}\right] 5$-HTP and the fact that $\left[{ }^{11} \mathrm{C}\right]$ AMT is not an ideal tracer for this purpose emphasize the complexity of measuring 5-HT synthesis. Although most properties of $\left[{ }^{11} \mathrm{C}\right] 5$-HTP seem appropriate, the difficult production of this radiopharmaceutical limits its widespread application. Future research should concentrate on elucidating what $\left[{ }^{11} \mathrm{C}\right] 5$-HTP is exactly measuring and improving tracer properties. Attempts to develop a novel tracer with improved properties should focus on: (1) specific uptake of the tracer by serotonergic neurons, (2) chemical modification of the radiopharmaceutical so that it is no longer converted to a 5-HIAA analogue and (3) a simplified production process.

\section{Conclusion}

We have reviewed several techniques for the evaluation of serotonin synthesis. PET can directly visualize this physiological process, whereas other techniques can only provide an indirect measurement. This makes it a valuable tool in clinical research especially because results indicate that serotonin synthesis seems to play a role in depression and antidepressant action, although widespread application of $\left[{ }^{11} \mathrm{C}\right] 5$-HTP and $\left[{ }^{11} \mathrm{C}\right]$ AMT in clinical research is not possible yet.

A unified theory of affective disorders can only be achieved if we consider different imaging methods and also take into account both animal and human histological data. In the future it may be worthwhile to develop the tools to study both receptor density and 5-HT synthesis, and this will hopefully yield a better and more complete understanding of the processes involved in the pathophysiology of affective disorders.

Conflicts of interest None.

Open Access This article is distributed under the terms of the Creative Commons Attribution Noncommercial License which permits any noncommercial use, distribution, and reproduction in any medium, provided the original author(s) and source are credited. 


\section{References}

1. Barnes NM, Sharp T. A review of central 5-HT receptors and their function. Neuropharmacology 1999;38(8):1083-152.

2. Fink KB, Göthert M. 5-HT receptor regulation of neurotransmitter release. Pharmacol Rev 2007;59(4):360-417.

3. Richardson-Jones JW, Craige CP, Guiard BP, Stephen A, Metzger KL, Kung HF, et al. 5-HT1A autoreceptor levels determine vulnerability to stress and response to antidepressants. Neuron 2010;65(1):40-52.

4. Dantzer R, O'Connor JC, Freund GG, Johnson RW, Kelley KW. From inflammation to sickness and depression: when the immune system subjugates the brain. Nat Rev Neurosci 2008;9 (1):46-56.

5. Bjurling $\mathrm{P}$, Watanabe $\mathrm{Y}$, Tokushige $\mathrm{M}$, Oda T, Långström B. Syntheses of $\beta$-11C-labelled L-tryptophan and 5-hydroxy-Ltryptophan using a multi-enzymatic reaction route. J Chem Soc Perkin Trans 1989;1(7):1331-4.

6. Blin J, Pappata S, Kiyosawa M, Crouzel C, Baron JC. [18F] setoperone: a new high-affinity ligand for positron emission tomography study of the serotonin-2 receptors in baboon brain in vivo. Eur J Pharmacol 1988;147(1):73-82.

7. Diksic M, Nagahiro S, Sourkes TL, Yamamoto YL. A new method to measure brain serotonin synthesis in vivo. I. Theory and basic data for a biological model. J Cereb Blood Flow Metab 1990;10(1):1-12.

8. Gallezot JD, Nabulsi N, Neumeister A, Planeta-Wilson B, Williams WA, Singhal T, et al. Kinetic modeling of the serotonin 5-HT(1B) receptor radioligand [(11)C]P943 in humans. J Cereb Blood Flow Metab 2010;30(1):196-210.

9. Halldin C, Lundberg J, Sóvágó J, Gulyás B, Guilloteau D, Vercouillie J, et al. [(11)C]MADAM, a new serotonin transporter radioligand characterized in the monkey brain by PET. Synapse 2005;58(3):173-83.

10. Herth MM, Piel M, Debus F, Schmitt U, Lüddens H, Rösch F. Preliminary in vivo and ex vivo evaluation of the 5-HT2A imaging probe [(18)F]MH.MZ. Nucl Med Biol 2009;36(4):44754.

11. Houle S, Ginovart N, Hussey D, Meyer JH, Wilson AA. Imaging the serotonin transporter with positron emission tomography: initial human studies with [11C]DAPP and [11C]DASB. Eur J Nucl Med 2000;27(11):1719-22.

12. Kumar JS, Prabhakaran J, Majo VJ, Milak MS, Hsiung SC, Tamir H, et al. Synthesis and in vivo evaluation of a novel 5HT1A receptor agonist radioligand [O-methyl-11C]2-(4-(4-(2methoxyphenyl)piperazin-1-yl)butyl)-4-methyl-1,2,4-triazine-3,5 $(2 \mathrm{H}, 4 \mathrm{H})$ dione in nonhuman primates. Eur J Nucl Med Mol Imaging 2007;34(7):1050-60.

13. Lang L, Jagoda E, Schmall B, Vuong BK, Adams HR, Nelson DL, et al. Development of fluorine-18-labeled 5-HT1A antagonists. J Med Chem 1999;42(9):1576-86.

14. Lemaire C, Cantineau R, Guillaume M, Plenevaux A, Christiaens L. Fluorine-18-altanserin: a radioligand for the study of serotonin receptors with PET: radiolabeling and in vivo biologic behavior in rats. J Nucl Med 1991;32(12):2266-72.

15. Lundkvist C, Halldin C, Ginovart N, Nyberg S, Swahn CG, Carr AA, et al. [11C]MDL 100907, a radioligland for selective imaging of 5-HT(2A) receptors with positron emission tomography. Life Sci 1996;58(10):PL 187-92.

16. Ma KH, Huang WS, Kuo YY, Peng CJ, Liou NH, Liu RS, et al. Validation of 4-[18F]-ADAM as a SERT imaging agent using micro-PET and autoradiography. Neuroimage 2009;45(3):68793.

17. Marner L, Gillings N, Comley RA, Baaré WF, Rabiner EA, Wilson AA, et al. Kinetic modeling of 11C-SB207145 binding to
5-HT4 receptors in the human brain in vivo. J Nucl Med 2009;50 (6): $900-8$

18. Pierson ME, Andersson J, Nyberg S, McCarthy DJ, Finnema SJ, Varnäs K, et al. [11C]AZ10419369: a selective 5-HT1B receptor radioligand suitable for positron emission tomography (PET). Characterization in the primate brain. Neuroimage 2008;41 (3):1075-85.

19. Pike VW, McCarron JA, Lammertsma AA, Osman S, Hume SP, Sargent PA, et al. Exquisite delineation of 5-HT1A receptors in human brain with PET and [carbonyl-11 C]WAY-100635. Eur J Pharmacol 1996;301(1-3):R5-7.

20. Pike VW, Halldin C, McCarron JA, Lundkvist C, Hirani E, Olsson H, et al. [carbonyl-11C]Desmethyl-WAY-100635 (DWAY) is a potent and selective radioligand for central 5HT1A receptors in vitro and in vivo. Eur J Nucl Med 1998;25 (4):338-46.

21. Sakai Y, Nishikawa M, Leyton M, Benkelfat C, Young SN, Diksic M. Cortical trapping of alpha-[(11)C]methyl-1-tryptophan, an index of serotonin synthesis, is lower in females than males. Neuroimage 2006;33(3):815-24.

22. Sandell J, Halldin C, Hall H, Thorberg SO, Werner T, Sohn D, et al. Radiosynthesis and autoradiographic evaluation of [11C] NAD-299, a radioligand for visualization of the 5-HT1A receptor. Nucl Med Biol 1999;26(2):159-64.

23. Shiue CY, Shiue GG, Mozley PD, Kung MP, Zhuang ZP, Kim HJ, et al. P-[18F]-MPPF: a potential radioligand for PET studies of 5-HT1A receptors in humans. Synapse 1997;25(2):147-54.

24. Suehiro M, Scheffel U, Ravert HT, Dannals RF, Wagner Jr HN. $[11 \mathrm{C}](+) \mathrm{McN} 5652$ as a radiotracer for imaging serotonin uptake sites with PET. Life Sci 1993;53(11):883-92.

25. Yasuno F, Zoghbi SS, McCarron JA, Hong J, Ichise M, Brown AK, et al. Quantification of serotonin 5-HT1A receptors in monkey brain with [11C](R)-(-)-RWAY. Synapse 2006;60(7):510-20.

26. Meltzer CC, Smith G, DeKosky ST, Pollock BG, Mathis CA, Moore RY, et al. Serotonin in aging, late-life depression, and Alzheimer's disease: the emerging role of functional imaging. Neuropsychopharmacology 1998;18(6):407-30.

27. Moresco RM, Matarrese M, Fazio F. PET and SPET molecular imaging: focus on serotonin system. Curr Top Med Chem 2006;6 (18):2027-34.

28. Kim C, Speisky MB, Kharouba SN. Rapid and sensitive method for measuring norepinephrine, dopamine, 5-hydroxytryptamine and their major metabolites in rat brain by high-performance liquid chromatography. Differential effect of probenecid, haloperidol and yohimbine on the concentrations of biogenic amines and metabolites in various regions of rat brain. J Chromatogr 1987;386:25-35.

29. Mignot E, Serrano A, Laude D, Elghozi JL, Dedek J, Scatton B. Measurement of 5-HIAA levels in ventricular CSF (by LCEC) and in striatum (by in vivo voltammetry) during pharmacological modifications of serotonin metabolism in the rat. $\mathrm{J}$ Neural Transm 1985;62(1-2):117-24.

30. Stenfors C, Ross SB. Changes in extracellular 5-HIAA concentrations as measured by in vivo microdialysis technique in relation to changes in 5-HT release. Psychopharmacology (Berl) 2004;172(2):119-28.

31. Diksic M, Young SN. Study of the brain serotonergic system with labeled alpha-methyl-L-tryptophan. J Neurochem 2001;78 (6): $1185-200$

32. Sneddon JM. Blood platelets as a model for monoaminecontaining neurones. Prog Neurobiol 1973;1(2):151-98.

33. Stahl SM. The human platelet. A diagnostic and research tool for the study of biogenic amines in psychiatric and neurologic disorders. Arch Gen Psychiatry 1977;34(5):509-16.

34. Bianchi M, Moser C, Lazzarini C, Vecchiato E, Crespi F. Forced swimming test and fluoxetine treatment: in vivo evidence that 
peripheral 5-HT in rat platelet-rich plasma mirrors cerebral extracellular 5-HT levels, whilst 5-HT in isolated platelets mirrors neuronal 5-HT changes. Exp Brain Res 2002;143 (2):191-7.

35. Janusonis S, Anderson GM, Shifrovich I, Rakic P. Ontogeny of brain and blood serotonin levels in 5-HT receptor knockout mice: potential relevance to the neurobiology of autism. J Neurochem 2006;99(3):1019-31.

36. Anderson GM, Mefford IN, Tolliver TJ, Riddle MA, Ocame DM, Leckman JF, et al. Serotonin in human lumbar cerebrospinal fluid: a reassessment. Life Sci 1990;46(4):24755.

37. van Praag HM, Korf J. Serotonin metabolism in depression: clinical application of the probenecid test. Int Pharmacopsychiatry 1974;9(1):35-51.

38. van Praag HM, de Haan S. Central serotonin metabolism and frequency of depression. Psychiatry Res 1979;1(3):219-24.

39. van Praag HM. Depression, suicide and the metabolism of serotonin in the brain. J Affect Disord 1982;4(4):275-90.

40. Barton DA, Esler MD, Dawood T, Lambert EA, Haikerwal D, Brenchley C, et al. Elevated brain serotonin turnover in patients with depression: effect of genotype and therapy. Arch Gen Psychiatry 2008;65(1):38-46.

41. van Praag HM, Kahn RS, Asnis GM, Wetzler S, Brown SL, Bleich A, et al. Denosologization of biological psychiatry or the specificity of 5-HT disturbances in psychiatric disorders. J Affect Disord 1987;13(1):1-8

42. Peremans K, Audenaert K, Hoybergs Y, Otte A, Goethals I, Gielen I, et al. The effect of citalopram hydrobromide on 5HT2A receptors in the impulsive-aggressive dog, as measured with 123I-5-I-R91150 SPECT. Eur J Nucl Med Mol Imaging 2005;32(6):708-16.

43. Goethals I, Vervaet M, Audenaert K, Van de Wiele C, Ham H, Vandecapelle M, et al. Comparison of cortical 5-HT2A receptor binding in bulimia nervosa patients and healthy volunteers. Am J Psychiatry 2004;161(10):1916-8.

44. van Heeringen C, Audenaert K, Van Laere K, Dumont F, Slegers G, Mertens J, et al. Prefrontal 5-HT2a receptor binding index, hopelessness and personality characteristics in attempted suicide. J Affect Disord 2003;74(2):149-58.

45. Audenaert K, Van Laere K, Dumont F, Vervaet M, Goethals I, Siegers G, et al. Decreased 5-HT2a receptor binding in patients with anorexia nervosa. J Nucl Med 2003;44(2):163-9.

46. Fernstrom JD, Wurtman RJ. Brain serotonin content: physiological dependence on plasma tryptophan levels. Science 1971;173 (992):149-52.

47. Fernstrom JD. Effects on the diet on brain neurotransmitters. Metabolism 1977;26(2):207-23.

48. Muzik O, Chugani DC, Chakraborty P, Mangner T, Chugani HT. Analysis of [C-11]alpha-methyl-tryptophan kinetics for the estimation of serotonin synthesis rate in vivo. J Cereb Blood Flow Metab 1997;17(6):659-69.

49. Tracqui P, Morot-Gaudry Y, Staub JF, Brézillon P, Perault-Staub AM, Bourgoin S, et al. Model of brain serotonin metabolism. II. Physiological interpretation. Am J Physiol 1983;244(2):R20615.

50. Roberge AG, Missala K, Sourkes TL. Alpha-methyltryptophan: effects on synthesis and degradation of serotonin in the brain. Neuropharmacology 1972;11(2):197-209.

51. Nagahiro S, Takada A, Diksic M, Sourkes TL, Missala K, Yamamoto YL. A new method to measure brain serotonin synthesis in vivo. II. A practical autoradiographic method tested in normal and lithium-treated rats. J Cereb Blood Flow Metab 1990;10(1):13-21.

52. Diksic M. alpha-Methyl tryptophan as a tracer for in vivo studies of brain serotonin system, from autoradiography to positron emission tomography. J Chem Neuroanat 1992;5 (4):349-54.

53. Vanier M, Tsuiki K, Grdisa M, Worsley K, Diksic M. Determination of the lumped constant for the alpha-methyltryptophan method of estimating the rate of serotonin synthesis. J Neurochem 1995;64 (2):624-35.

54. Diksic M. Labelled alpha-methyl-L-tryptophan as a tracer for the study of the brain serotonergic system. J Psychiatry Neurosci 2001;26(4):293-303.

55. Patlak CS, Blasberg RG, Fenstermacher JD. Graphical evaluation of blood-to-brain transfer constants from multiple-time uptake data. J Cereb Blood Flow Metab 1983;3(1):1-7.

56. Gharib A, Balende C, Sarda N, Weissmann D, Plenevaux A, Luxen A, et al. Biochemical and autoradiographic measurements of brain serotonin synthesis rate in the freely moving rat: a reexamination of the alpha-methyl-L-tryptophan method. J Neurochem 1999;72(6):2593-600.

57. Shoaf SE, Carson RE, Hommer D, Williams WA, Higley JD, Schmall B, et al. The suitability of [11C]-alpha-methyl-Ltryptophan as a tracer for serotonin synthesis: studies with dual administration of [11C] and [14C] labeled tracer. J Cereb Blood Flow Metab 2000;20(2):244-52.

58. Diksic M. Does labeled alpha-methyl-L-tryptophan image ONLY blood-brain barrier transport of tryptophan? J Cereb Blood Flow Metab 2000;20(10):1508-11.

59. Chugani DC, Muzik O. Alpha[C-11]methyl-L-tryptophan PET maps brain serotonin synthesis and kynurenine pathway metabolism. J Cereb Blood Flow Metab 2000;20(1):2-9.

60. Cohen Z, Tsuiki K, Takada A, Beaudet A, Diksic M, Hamel E. In vivo-synthesized radioactively labelled alpha-methyl serotonin as a selective tracer for visualization of brain serotonin neurons. Synapse 1995;21(1):21-8.

61. Mück-Seler D, Jevric-Causevic A, Diksic M. Influence of fluoxetine on regional serotonin synthesis in the rat brain. $\mathrm{J}$ Neurochem 1996;67(6):2434-42.

62. Tsuiki K, Yamamoto YL, Diksic M. Effect of acute fluoxetine treatment on the brain serotonin synthesis as measured by the alpha-methyl-L-tryptophan autoradiographic method. J Neurochem 1995;65(1):250-6.

63. Hasegawa S, Watanabe A, Nguyen KQ, Debonnel G, Diksic M. Chronic administration of citalopram in olfactory bulbectomy rats restores brain 5-HT synthesis rates: an autoradiographic study. Psychopharmacology (Berl) 2005;179(4): 781-90.

64. Okazawa H, Yamane F, Blier P, Diksic M. Effects of acute and chronic administration of the serotonin $1 \mathrm{~A}$ agonist buspirone on serotonin synthesis in the rat brain. J Neurochem 1999;72 (5):2022-31.

65. Sharp T, Bramwell SR, Grahame-Smith DG. 5-HT1 agonists reduce 5-hydroxytryptamine release in rat hippocampus in vivo as determined by brain microdialysis. Br J Pharmacol 1989;96 (2):283-90.

66. VanderMaelen CP, Matheson GK, Wilderman RC, Patterson LA. Inhibition of serotonergic dorsal raphe neurons by systemic and iontophoretic administration of buspirone, a non-benzodiazepine anxiolytic drug. Eur J Pharmacol 1986;129(1-2):123-30.

67. Tohyama Y, Yamane F, Fikre Merid M, Blier P, Diksic M. Effects of serotine receptors agonists, TFMPP and CGS12066B, on regional serotonin synthesis in the rat brain: an autoradiographic study. J Neurochem 2002;80(5):788-98.

68. Vergé D, Daval G, Marcinkiewicz M, Patey A, el Mestikawy S, Gozlan H, et al. Quantitative autoradiography of multiple 5-HT1 receptor subtypes in the brain of control or 5,7-dihydroxytryptamine-treated rats. J Neurosci 1986;6(12):3474-82.

69. Hasegawa S, Watanabe A, Nishi K, Nguyen KQ, Diksic M. Selective 5-HT1B receptor agonist reduces serotonin synthesis 
following acute, and not chronic, drug administration: results of an autoradiographic study. Neurochem Int 2005;46(3):261-72.

70. Hasegawa S, Kanemaru K, Gittos M, Diksic M. The tryptophan hydroxylase activation inhibitor, AGN-2979, decreases regional 5-HT synthesis in the rat brain measured with alpha-[14C] methyl-L-tryptophan: an autoradiographic study. Brain Res Bull 2005;67(3):248-55.

71. Tohyama Y, Takahashi S, Merid MF, Watanabe A, Diksic M. The inhibition of tryptophan hydroxylase, not protein synthesis, reduces the brain trapping of alpha-methyl-L-tryptophan: an autoradiographic study. Neurochem Int 2002;40(7):603-10.

72. Mück-Seler D, Diksic M. The acute effects of reserpine and NSD-1015 on the brain serotonin synthesis rate measured by an autoradiographic method. Neuropsychopharmacology 1995;12 (3):251-62.

73. Treseder SA, Rose S, Summo L, Jenner P. Commonly used L-amino acid decarboxylase inhibitors block monoamine oxidase activity in the rat. J Neural Transm 2003;110 (3):229-38.

74. Diksic M, Nagahiro S, Chaly T, Sourkes TL, Yamamoto YL, Feindel W. Serotonin synthesis rate measured in living dog brain by positron emission tomography. J Neurochem 1991;56(1):15362.

75. Nishisawa S, Mzengeza S, Diksic M. Acute effects of 3,4methylenedioxymethamphetamine on brain serotonin synthesis in the dog studied by positron emission tomography. Neurochem Int 1999;34(1):33-40.

76. Molliver ME, Berger UV, Mamounas LA, Molliver DC, O'Hearn E, Wilson MA. Neurotoxicity of MDMA and related compounds: anatomic studies. Ann N Y Acad Sci 1990;600:649-61.

77. Shoaf SE, Carson R, Hommer D, Williams W, Higley JD, Schmall B, et al. Brain serotonin synthesis rates in rhesus monkeys determined by [11C]alpha-methyl-L-tryptophan and positron emission tomography compared to CSF 5hydroxyindole-3-acetic acid concentrations. Neuropsychopharmacology 1998;19(5):345-53.

78. Nishizawa S, Benkelfat C, Young SN, Leyton M, Mzengeza S, de Montigny $\mathrm{C}$, et al. Differences between males and females in rates of serotonin synthesis in human brain. Proc Natl Acad Sci U S A 1997;94(10):5308-13.

79. Leyton M, Diksic M, Benkelfat C. Brain regional alpha-[11C] methyl-L-tryptophan trapping correlates with post-mortem tissue serotonin content and [11C]5-hydroxytryptophan accumulation. Int J Neuropsychopharmacol 2005;8(4):633-4.

80. Nishizawa S, Leyton M, Okazawa H, Benkelfat C, Mzengeza S, Diksic M. Validation of a less-invasive method for measurement of serotonin synthesis rate with alpha-[11C]methyl-tryptophan. J Cereb Blood Flow Metab 1998;18(10):1121-9.

81. Tanke MA, Alserda E, Doornbos B, van der Most PJ, Goeman $\mathrm{K}$, Postema $\mathrm{F}$, et al. Low tryptophan diet increases stresssensitivity, but does not affect habituation in rats. Neurochem Int 2008;52(1-2):272-81.

82. Van der Does AJ. The effects of tryptophan depletion on mood and psychiatric symptoms. J Affect Disord 2001;64(2-3):10719

83. Jans LA, Riedel WJ, Markus CR, Blokland A. Serotonergic vulnerability and depression: assumptions, experimental evidence and implications. Mol Psychiatry 2007;12(6):522-43.

84. Chugani DC, Muzik O, Chakraborty P, Mangner T, Chugani HT. Human brain serotonin synthesis capacity measured in vivo with alpha-[C-11]methyl-L-tryptophan. Synapse 1998;28 (1):33-43

85. Davis JN, Carlsson A, MacMillan V, Siesjo BK. Brain tryptophan hydroxylation: dependence on arterial oxygen tension. Science 1973;182(107):72-4.
86. Nishikawa M, Kumakura Y, Young SN, Fiset P, Vogelzangs N, Leyton $\mathrm{M}$, et al. Increasing blood oxygen increases an index of 5-HT synthesis in human brain as measured using alpha-[(11)C] methyl-L-tryptophan and positron emission tomography. Neurochem Int 2005;47(8):556-64.

87. Rosa-Neto P, Diksic M, Okazawa H, Leyton M, Ghadirian N, Mzengeza S, et al. Measurement of brain regional alpha-[11C] methyl-L-tryptophan trapping as a measure of serotonin synthesis in medication-free patients with major depression. Arch Gen Psychiatry 2004;61(6):556-63.

88. Drevets WC. Neuroimaging and neuropathological studies of depression: implications for the cognitive-emotional features of mood disorders. Curr Opin Neurobiol 2001;11(2):240-9.

89. Berney A, Nishikawa M, Benkelfat C, Debonnel G, Gobbi G, Diksic M. An index of 5-HT synthesis changes during early antidepressant treatment: alpha-[11C]methyl-L-tryptophan PET study. Neurochem Int 2008;52(4-5):701-8.

90. Artigas F, Perez V, Alvarez E. Pindolol induces a rapid improvement of depressed patients treated with serotonin reuptake inhibitors. Arch Gen Psychiatry 1994;51(3):24851

91. Lejeune F, Millan MJ. Pindolol excites dopaminergic and adrenergic neurons, and inhibits serotonergic neurons, by activation of 5-HT1A receptors. Eur J Neurosci 2000;12 (9):3265-75.

92. Cremers TI, Wiersma LJ, Bosker FJ, Den Boer JA, Westerink $\mathrm{BH}$, Wikström $\mathrm{HV}$. Is the beneficial antidepressant effect of coadministration of pindolol really due to somatodendritic autoreceptor antagonism? Biol Psychiatry 2001;50 (1):13-21.

93. Frey BN, Rosa-Neto P, Lubarsky S, Diksic M. Correlation between serotonin synthesis and 5-HT1A receptor binding in the living human brain: a combined alpha-[11C]MT and [18F]MPPF positron emission tomography study. Neuroimage 2008;42 (2):850-7.

94. Batista CE, Juhász C, Muzik O, Kupsky WJ, Barger G, Chugani $\mathrm{HT}$, et al. Imaging correlates of differential expression of indoleamine 2,3-dioxygenase in human brain tumors. Mol Imaging Biol 2009;11(6):460-6.

95. Hartvig P, Bergström M, Antoni G, Langstrom B. Positron emission tomography and brain monoamine neurotransmission entries for study of drug interactions. Curr Pharm Des 2002;8 (16):1417-34

96. Koopmans KP, Neels OC, Kema IP, Elsinga PH, Sluiter WJ, Vanghillewe $\mathrm{K}$, et al. Improved staging of patients with carcinoid and islet cell tumors with 18F-dihydroxy-phenyl-alanine and 11C-5-hydroxy-tryptophan positron emission tomography. J Clin Oncol 2008;26(9):1489-95.

97. Orlefors H, Sundin A, Lu L, Oberg K, Långström B, Eriksson B, et al. Carbidopa pretreatment improves image interpretation and visualisation of carcinoid tumours with 11C-5-hydroxytryptophan positron emission tomography. Eur J Nucl Med Mol Imaging 2006;33(1):60-5.

98. Bombardieri E, Maccauro M, De Deckere E, Savelli G, Chiti A. Nuclear medicine imaging of neuroendocrine tumours. Ann Oncol 2001;12 Suppl 2:S51-61.

99. Neels OC, Koopmans KP, Jager PL, Vercauteren L, van Waarde A, Doorduin J, et al. Manipulation of [11C]-5-hydroxytryptophan and 6-[18F]fluoro-3,4-dihydroxy-L-phenylalanine accumulation in neuroendocrine tumor cells. Cancer Res 2008;68 (17):7183-90.

100. Hartvig P, Lindner KJ, Tedroff $\mathrm{J}$, Andersson $\mathrm{Y}$, Bjurling $\mathrm{P}$, Långström B. Brain kinetics of 11 C-labelled L-tryptophan and 5-hydroxy-L-tryptophan in the rhesus monkey. A study using positron emission tomography. J Neural Transm Gen Sect 1992;88(1):1-10. 
101. Lindner KJ, Hartvig P, Bjurling P, Fasth KJ, Westerberg G, Långström B. Determination of 5-hydroxy-L-[beta-11C]tryptophan and its in vivo-formed radiolabeled metabolites in brain tissue using high performance liquid chromatography: a study supporting radiotracer kinetics obtained with positron emission tomography. Nucl Med Biol 1997;24(8):733-8.

102. Hartvig P, Lindner KJ, Bjurling P, Laengstrom B, Tedroff J, Pyridoxine effect on synthesis rate of serotonin in the monkey brain measured with positron emission tomography. J Neural Transm Gen Sect 1995;102(2):91-7.

103. Hartvig P, Tedroff J, Lindner KJ, Bjurling P, Chang CW, Tsukada $\mathrm{H}$, et al. Positron emission tomographic studies on aromatic Lamino acid decarboxylase activity in vivo for L-dopa and 5hydroxy-L-tryptophan in the monkey brain. J Neural Transm Gen Sect 1993;94(2):127-35.

104. Arai R, Karasawa N, Nagatsu T, Nagatsu I. Exogenous L-5hydroxytryptophan is decarboxylated in neurons of the substantia nigra pars compacta and locus coeruleus of the rat. Brain Res 1995;669(1):145-9.

105. Lundquist P, Blomquist G, Hartvig P, Hagberg GE, Torstenson $\mathrm{R}$, Hammarlund-Udenaes $\mathrm{M}$, et al. Validation studies on the 5hydroxy-L-[beta-11C]-tryptophan/PET method for probing the decarboxylase step in serotonin synthesis. Synapse 2006;59 (8):521-31.

106. Lundquist P, Hartvig P, Blomquist G, Hammarlund-Udenaes $\mathrm{M}$, Långström B. 5-Hydroxy-L-[beta-(11)C]tryptophan versus alpha-[(11)C]methyl-L-tryptophan for positron emission to- mography imaging of serotonin synthesis capacity in the rhesus monkey brain. J Cereb Blood Flow Metab 2007;27 (4):821-30.

107. Agren H, Reibring L, Hartvig P, Tedroff J, Bjurling P, Hömfeldt K, et al. Low brain uptake of $\mathrm{L}$-[11C]5-hydroxytryptophan in major depression: a positron emission tomography study on patients and healthy volunteers. Acta Psychiatr Scand 1991;83(6):449-55.

108. Eriksson O, Wall A, Marteinsdottir I, Agren H, Hartvig P, Blomqvist $\mathrm{G}$, et al. Mood changes correlate to changes in brain serotonin precursor trapping in women with premenstrual dysphoria. Psychiatry Res 2006;146(2):107-16.

109. Hagberg GE, Torstenson R, Marteinsdottir I, Fredrikson M, Långström B, Blomqvist G. Kinetic compartment modeling of [11C]-5-hydroxy-L-tryptophan for positron emission tomography assessment of serotonin synthesis in human brain. J Cereb Blood Flow Metab 2002;22(11):1352-66.

110. Neels OC, Jager PL, Koopmans KP, Eriks E, de Vries EGE, Kema IP, et al. Development of a reliable remote-controlled synthesis of beta-[C-11]-5-hydroxy-L-tryptophan on a Zymark robotic system. J Labelled Comp Radiopharm 2006;49(10):889-95.

111. Agren H, Reibring L. PET studies of presynaptic monoamine metabolism in depressed patients and healthy volunteers. Pharmacopsychiatry 1994;27(1):2-6.

112. Lynn-Bullock CP, Welshhans K, Pallas SL, Katz PS. The effect of oral 5-HTP administration on 5-HTP and 5-HT immunoreactivity in monoaminergic brain regions of rats. J Chem Neuroanat 2004;27(2):129-38. 